\title{
T-helper cells as new players in ANCA-associated vasculitides
}

\author{
Wayel H Abdulahad*, Peter Lamprecht ${ }^{2}$ and Cees GM Kallenberg
}

\begin{abstract}
In anti-neutrophil cytoplasmic autoantibodyassociated vasculitides (AAV), several observations support a key role of T-helper cells (CD4+ T cells) in disease pathophysiology. An expanded population of effector memory $\mathrm{CD}^{+} \mathrm{T}$ cells in AAV patients may contribute to tissue injury and disease progression. In addition, functional impairment of regulatory $T$ cells $\left(T_{\text {Regs }}\right)$ is reported in AAV patients. A fraction of $T_{\text {Regs }}$ have the capacity to differentiate into Th17 cells in the context of a proinflammatory environment. Therefore, nonfunctionality of $\mathrm{T}_{\text {Regs }}$ described in AAV patients may be caused by their conversion into IL-17-producing cells that may contribute to granulomatous vasculitis. Further investigations directed at the plasticity of $\mathrm{T}_{\text {Regs }}$ in AAV patients are warranted.
\end{abstract}

\section{Introduction}

Anti-neutrophil cytoplasmic autoantibody (ANCA)associated vasculitides (AAV) constitutes a group of disorders characterized by autoimmune necrotizing inflammation of small blood vessels, which leads to systemic organ damage [1]. This group of systemic vasculitides includes Wegener's granulomatosis (WG), microscopic polyangiitis (MPA), and Churg-Strauss syndrome (CSS). These disorders are predominantly associated with the presence of circulating ANCAs that are directed against proteins in the cytoplasmic granules of neutrophils. ANCAs with specificity for proteinase-3 (PR3-ANCA) are associated with WG to a high degree, whereas ANCAs with specificity for myeloperoxidase (MPO-ANCA) are predominant in MPA and to a lesser degree in CSS [2]. Although it remains unknown how these conditions develop, it has been postulated that

\footnotetext{
*Correspondence: w.abdulahad@reuma.umcg.nl

'Department of Rheumatology and Clinical Immunology, University Medical Center Groningen, Hanzeplein 1, 9713 GZ Groningen, The Netherlands Full list of author information is available at the end of the article
}

ANCA in vivo bind to surface-expressed autoantigens (PR3 or MPO) on primed neutrophils, which enhances neutrophil degranulation and the release of toxic products that cause endothelial damage, ultimately leading to necrotizing vasculitis [2].

In vivo experimental studies have clearly demonstrated that MPO-ANCAs are pathogenic factors. Xiao and colleagues have shown that immunization of MPOdeficient mice with mouse MPO results in an MPOdirected immune response, and transfer of splenocytes from these mice into immune-deficient mice leads to development of pauci-immune necrotizing crescentic glomerulonephritis and systemic necrotizing vasculitis reminiscent of MPA [3]. Further support for the pathogenicity of ANCA comes from a recent study by van Timmeren and coworkers [4]. They observed that administration of anti-MPO antibodies hydrolyzed by the bacterial enzyme endoglycosidase $S$, which abolishes IgG binding to $\mathrm{Fc} \gamma$ receptors, attenuated both neutrophil influx and formation of glomerular crescents in the abovedescribed model of MPO-ANCA-induced glomerulonephritis. An immunopathogenic role for MPO-ANCA has also been strongly suggested by the occurrence of neonatal MPA in a child born to a mother with a history of MPO-ANCA-associated pulmonary renal syndrome [5].

In contrast to MPO-ANCA, in vivo evidence is still lacking for a direct vasculitic pathogenicity of PR3ANCA. So far only PR3-induced and PR3-ANCA-induced enhancement of inflammation has been demonstrated in an animal model [6,7]. Recent findings by Primo and colleagues suggest that, under certain conditions, antiPR3 antibodies can be pathogenic in rodents [8]. They showed that adoptive transfer of splenocytes from PR3immunized mice into NOD-SCID mice resulted in the appearance of circulating anti-PR3 antibodies and crescentic glomerulonephritis in the recipient mice. However, it is unclear whether glomerulonephritis in recipient mice is mediated by the humoral or the cellular arm of the anti-PR3 response.

Of note, infiltrating $\mathrm{T}$ cells in granulomatous lesions as well as persistent $\mathrm{T}$-cell activation have been reported in AAV patients [9-12]. Interestingly, T-cell-depleting therapy with anti-CD52 antibodies (alemtuzumab) and 
anti-thymocyte globulin can induce remission in refractory AAV patients [13,14]. Moreover, the IgG subclass distribution of ANCA, predominantly consisting of $\operatorname{IgG}_{1}$ and $\operatorname{IgG}_{4}$, implies isotype switching of ANCA for which CD4 T-helper cells are required [15]. T-cellmediated immunity is thus thought to contribute to the pathogenesis of ANCA-associated vasculitis. In the present review we will summarize the currently available data on the role of $\mathrm{T}$ cells in AAV. We shall first discuss current thoughts about the contribution of $\mathrm{T}$ cells to tissue injury in AAV. The main emphasis will then be on the plasticity of regulatory $\mathrm{T}$ cells $\left(\mathrm{T}_{\text {Regs }}\right)$, their transition into Th17 cells, and the involvement of Th17 cells in granuloma formation and disease progression.

\section{Involvement of CD4 T cells in AAV}

Unlike other autoantibody-mediated diseases, AAV is characterized by an absence of deposited antibodies in affected tissue, in particular in glomeruli, designated as pauci-immune glomerular lesions [16]. Otherwise, immune effector cells such as CD4 ${ }^{+} \mathrm{T}$ cells, macrophages and granulocytes are enriched in granulomatous lesions [9,10,17-20]. This suggests a primary role of cell-mediated immunity in initiating granuloma formation. Studies in mice and humans have demonstrated a key role of CD4 ${ }^{+}$ $\mathrm{T}$ cells in the generation of a granulomatous response. For instance, Saunders and colleagues have shown that CD4-deficient mice did not generate the typical mononuclear granulomatous lesions following Mycobacterium tuberculosis infection [21]. In humans, the extent of granuloma formation was correlated with peripheral CD4 T-cell counts in HIV patients with mycobacterial infection [22,23]. The important role of CD4 $\mathrm{T}$ cells in the expression of crescentic glomerulonephritis has been demonstrated by Ruth and colleagues [24]. They induced experimental anti-MPO-associated crescentic glomerulonephritis by immunizing C57BL/6 mice with human MPO followed by subsequent challenge with antiglomerular basement membrane antibodies. Mice depleted of $\mathrm{CD}_{4}^{+} \mathrm{T}$ cells at the time of administration of anti-mouse glomerular basement membrane developed significantly less glomerular crescent formation and less cell influx when compared with control mice. These data provide convincing evidence that $\mathrm{CD}_{4}^{+} \mathrm{T}$ cells are crucial in granuloma formation and glomerulonephritis.

Studies in AAV patients also support this notion. Proliferation of $\mathrm{CD}^{+} \mathrm{T}$ cells in response to the autoantigens PR3 and MPO have been reported in patients with AAV, although CD4 ${ }^{+} \mathrm{T}$ cells from healthy controls also proliferated in response to PR3 and MPO, albeit to a lesser extent [25]. Persistent CD4 T-cell activation has also been observed in peripheral blood from AAV patients [26-28]. Importantly, Marinaki and colleagues observed an association between persistent CD4+ $4^{+}$-cell activation and disease severity in both WG patients and MPA patients [29]. Recently, Seta and colleagues evaluated the effect of depleting CD4 or CD8 T cells on the proliferative response to MPO fragments of peripheral blood mononuclear cells isolated from MPA patients [30]. Strikingly, proliferation was completely lost after the depletion of $\mathrm{CD}^{+}{ }^{+} \mathrm{T}$ cells, but not after depletion of $\mathrm{CD}^{+} \mathrm{T}$ cells. In our studies in WG patients, we observed a persistent expansion of a subset of memory $\mathrm{CD}^{+}{ }^{+} \mathrm{T}$ cells, termed effector memory $\mathrm{T}$ cells $\left(\mathrm{T}_{\mathrm{EM}}\right)$, with a reciprocal decrease in naïve $\mathrm{CD}^{+} \mathrm{T}$ cells [11]. Moreover, the $\mathrm{CD}^{+}{ }^{+} \mathrm{T}$-cell compartment also appears to be altered [31,32]. In accordance, infiltrating $\mathrm{T}$ cells in lung lesions and glomeruli were shown to consist mainly of $\mathrm{CD}^{+} \mathrm{T}$ cells with a memory phenotype $[9,33,34]$. Also in CSS patients, given the allergic background and hypereosinophilia in this disease, activated $\mathrm{CD}^{+} \mathrm{T}$ cells producing Th2 cytokines are believed to be the disease inducer [35]. Taken together, these findings indicate that CD4 T cells can serve as effector cells in the pathogenesis of AAV.

\section{CD4+ effector memory T cells: a key player in tissue injury in AAV}

As mentioned above, several observations support the involvement of $\mathrm{CD}^{+} \mathrm{T}$ cells in the pathogenesis of AAV. Important evidence regarding their role in disease manifestations came also from the clinical observation that remission could be induced in WG patients by antibodies directed at $\mathrm{T}$ cells [36]. Indeed, an altered phenotype of $\mathrm{CD}^{+} \mathrm{T}$ cells has been found in AAV patients. An increased proportion of $\mathrm{CD} 45 \mathrm{RC} \mathrm{L}^{\mathrm{Low}} \mathrm{CD} 4^{+}$memory $\mathrm{T}$ cells was reported in peripheral blood of AAV patients [37]. In addition, an expanded population of $\mathrm{CD}^{+} \mathrm{T}$ cells lacking the co-stimulatory molecule CD28 was observed in peripheral blood and in granulomatous lesions of patients with WG $[9,38]$. These $\mathrm{CD}^{2} 8^{-} \mathrm{CD}^{+} \mathrm{T}$ cells display upregulation of the $\mathrm{T}$-cell differentiation marker CD57 and show intracytoplasmic perforin expression, indicating the cytotoxic potential of these cells [9]. Based on phenotype and functional characteristics, CD28 ${ }^{-} \mathrm{T}$ cells have been classified as a $\mathrm{T}_{\mathrm{EM}}$ population that lacks the chemokine receptor CCR7 [39].

Consistent with these findings, we observed a significant increase in the frequency of circulating $\mathrm{CD}_{4}^{+}$

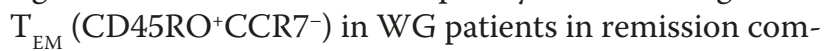
pared with healthy individuals [11]. In addition, we have shown that the number of these circulating $C D 4^{+} \mathrm{T}_{\mathrm{EM}}$ decreases during active disease compared with that during complete remission, which is consistent with their migration towards inflamed tissues [11]. Indeed, our cross-sectional and follow-up studies confirmed migration of $\mathrm{CD}^{+} \mathrm{T}_{\mathrm{EM}}$ during active renal disease into the diseased organs [40]. We observed a remarkable 
increase in $\mathrm{CD}^{+} \mathrm{T}_{\mathrm{EM}}$ in the urinary sediment with a concomitant decrease of circulating $\mathrm{CD}^{+} \mathrm{T}_{\mathrm{EM}}$ of WG patients with active renal involvement [40]. These urinary $\mathrm{CD} 4^{+} \mathrm{T}_{\mathrm{EM}}$ decreased or disappeared from the urine during remission, which might reflect their role in renal injury. In accordance with these findings, Wilde and colleagues demonstrated that $\mathrm{CD}^{+} \mathrm{T}_{\mathrm{EM}}$ expressing CD134 are expanded in peripheral blood of patients with WG [41]. CD134 is thought to contribute to T-cell migration and tissue infiltration through its interaction with OX40L on vascular endothelial cells [42]. Indeed, Wilde and coworkers have shown that CD134-expressing T cells were localized within the inflammatory lesions of WG patients, supporting our hypothesis on migration of this T-cell subset to inflamed sites [41].

As mentioned, $\mathrm{CD} 4^{+} \mathrm{T}_{\mathrm{EM}}$ display natural killer (NK)like features such as cytotoxicity [39]. They also mimic NK cells by their surface expression of the NKG2D molecule. NKG2D is an activating C-type lectin-like homodimeric receptor, which differs from other NKG2 members as it apparently lacks an antagonist and substitutes for CD28-mediated co-stimulatory signaling in CD28- $\mathrm{T}_{\mathrm{EM}}$ [43]. One of the NKG2D ligands is the major histocompatibility complex class-I chain-related molecule A (MICA), which is expressed upon cellular injury and stress on target cells such as fibroblasts and epithelial cells [43]. Proof of concept for NKG2D-mediated tissue destruction was provided by Allez and colleagues [44], who demonstrated that $\mathrm{NKG}_{2} \mathrm{D}^{+} \mathrm{CD} 4^{+} \mathrm{T}$-cell clones from patients with Crohn's disease kill target cells that express MICA via NKG2D-MICA interaction. Importantly, MICA is upregulated in peritubular endothelium and glomerular epithelial cells in AAV patients during active renal disease [45]. Strikingly, Capraru and colleagues have shown that NKG2D is preferentially expressed on expanded $\mathrm{CD} 28^{-} \mathrm{CD} 4^{+} \mathrm{T}$ cells in the peripheral blood of WG patients [31]. Next, they showed that both NKG2D and MICA are expressed in granulomatous lesions in WG, but not in disease controls. Killing mechanisms via NKG2D-MICA interaction therefore probably contribute to vessel injury and disease progression in AAV patients (Figure 1). Accordingly, selective targeting of NKG2D ${ }^{+} \mathrm{CD} 4^{+} \mathrm{T}_{\mathrm{EM}}$ or inhibiting MICA expression without impairing other parts of cellular immunity might have value in the treatment of AAV [46].

\section{Th1/Th2/Th17 paradigm in AAV}

Aberrant T-helper cell polarization has been described in AAV. Analysis of soluble markers for T-helper cell subsets in patient sera reveals a predominance of the Th1 pattern with expression of IFNY and sCD26 in patients with localized WG and in patients with MPA, whereas a shift towards a Th2 pattern, with expression of IL-4, IL-5, IL-10, IL-13, sCD23, and sCD30, was observed in active generalized WG and CSS [47,48]. The same results were obtained from analysis of nasal granulomatous lesions in which abundant Th1-associated markers (IFN $\gamma$, sCD26, CCR5) were seen during localized WG, whereas Th1associated and Th2-associated markers (IL-4 and CCR3) are found in generalized WG $[20,49]$. Besides the balance between Th1 and Th2, a recent breakthrough has revealed that IL-17-secreting T cells (Th17) are another major pathogenic effector subset involved in the induction of inflammation and autoimmunity [50,51]. It has been reported that induction of experimental autoimmune encephalomyelitis (EAE) was blocked in mice deficient in either IL-17 or the Th17 polarizing cytokine IL-23, whereas mice deficient in either IFNY or the Th1 polarizing cytokine IL-12 show increased susceptibility to EAE [50,52,53]. Interestingly, Th17 cells in EAE infiltrate the brain prior to the onset of clinical symptoms, whereas Th1 cells dominate the cellular infiltrate thereafter when clinical disease develops [54]. It seems that T-cell-mediated disease manifestations are linked to Th17 cells and not primarily to Th1 responses.

The physiological role of Th17 cells lies in bacterial defense - for example, against Staphylococcus aureus as shown in experimental pneumonia and the hyper-IgE syndrome [55,56]. Peptidoglycans as well as superantigens from $S$. aureus might have an immunomodulatory effect on dendritic cells by imprinting of a strong Th17 polarizing capacity [57]. In addition, S. aureus $\alpha$-toxin was shown to induce IL-17A secretion in CD4 $\mathrm{T}$ cells [58]. Intriguingly, nasal S. aureus co-localization has been reported to be related to relapse and correlates with endonasal activity in WG $[59,60]$. Infection with S. aureus might therefore drive a Th17 response in AAV patients. Indeed, in patients with AAV we observed a skewing towards Th17 cells following in vitro stimulation of peripheral blood samples [61]. In line with this observation, Ordonez and coworkers have shown that the expanded $\mathrm{CD} 4^{+}$memory $\mathrm{T}$ cells in AAV patients are a source of IL-17 [37]. Most importantly, we found a relative increase in autoantigen-specific Th17 cells in ANCA-positive patients in comparison with ANCAnegative patients and controls [61]. This observation suggests involvement of Th17 cells in the process of autoantibody production in AAV. These results were corroborated by Nogueira and colleagues, who reported elevated levels of serum IL-17A and increased autoantigen-specific Th17 cells in AAV patients during disease convalescence compared with healthy controls [62]. In addition, Saito and colleagues observed an increased frequency of circulating Th17 cells in patients with active CSS compared with in patients with inactive disease and healthy controls [63].

IL-17 has been reported to promote the release of proinflammatory cytokines, which are essential for triggering 
the expression of PR3 and MPO on the surface of neutrophils (priming of neutrophils), and also to induce CXC chemokine release and expression of adhesion molecules responsible for the recruitment of neutrophils to the site of inflammation [64-66]. Indeed, WG granulomata (site of inflammation) are rich in neutrophils [20]. On the other hand, IL-17 has been shown crucial for the formation of an autoreactive germinal center in autoimmune BXD2 mice [67]. IL-17-producing T cells and B cells expressing the IL-17 receptor have also been reported to localize together in germinal centers [67]. This observation suggests that IL-17 not only induces tissue inflammation but also could function on B cells to promote the germinal center reaction. The lymphocyte clusters in granuloma structures can resemble germinal center-like structures that might be induced by IL-17 and may provide a place for ANCA production. IL-17 thus seems to be an important player in disease development in AAV and in early granuloma formation in WG, whereas Th1 and Th2 cells might prevail in later stages $[20,49]$. Of note, Th17 cells have not so far been demonstrated at inflamed sites in AAV.

\section{Disturbance in the frequency and/or function of regulatory $T$ cells in AAV}

Natural $\mathrm{T}_{\text {Regs }}$, a subset of thymus-derived CD4 $4^{+} \mathrm{T}$ cells expressing a high level of IL-2R $\alpha$ (CD25) and a unique transcription factor FoxP3, have been shown critical for preventing autoimmune responses. Defects in $\mathrm{T}_{\mathrm{Reg}}$ function or reduced numbers of $T_{\text {Regs }}$ have been documented in several autoimmune diseases [68]. Indeed, we found that the suppressive function of $T_{\text {Regs }}$ was defective in WG patients as compared with healthy controls [69]. In this group of patients, however, we observed a significant increase of memory FoxP $3^{+} \mathrm{CD} 25^{\text {High }} \mathrm{T}_{\text {Regs }}$. In line with these findings, Klapa and colleagues demonstrated an increased number of FoxP3+ $\mathrm{T}$ cells as well as phenotypical and functional alterations of $\mathrm{T}_{\text {Regs }}$ in WG patients [70]. They reported an increased number of interferon receptor I-positive $\mathrm{T}_{\text {Regs }}$ in the peripheral blood of WG patients [70]. In addition, they showed that IFN $\alpha$ exaggerates functional $\mathrm{T}_{\text {Reg }}$ impairment ex vivo in response to the autoantigen PR3 [70]. $\mathrm{T}_{\text {Regs }}$ in WG patients might thus display functional anergy in the context of an inflammatory cytokine milieu.

Altered $\mathrm{T}_{\text {Reg }}$ function in WG patients has also been reported by Morgan and coworkers [71]. They observed that $\mathrm{T}_{\text {Regs }}$ from healthy controls and from ANCA-negative patients were able to suppress T-cell proliferation to PR3, whereas $\mathrm{T}_{\text {Regs }}$ from ANCA-positive patients failed to suppress this autoimmune response [71]. Dysfunction of $\mathrm{T}_{\text {Regs }}$ is thus believed to play a role in the development of WG. In contrast, $T_{\text {Reg }}$ function in MPA patients was comparable with that in healthy controls, but FoxP3 levels were diminished in MPA patients [72]. MPA seems to be associated with a numerical deficiency rather than a functional deficiency of $\mathrm{T}_{\text {Regs }}$. Moreover, studies in CSS patients showed that both patients and controls have a similar number of $\mathrm{CD} 25^{+} \mathrm{CD} 4^{+} \mathrm{T}$ cells with an equal percentage of FoxP3-expressing cells. However, the suppressive function of $\mathrm{T}_{\text {Regs }}$ in CSS patients still needs to be investigated [63,73].

\section{Plasticity of $\mathrm{T}_{\text {Regs }}$ in AAV: conversion towards Th17 effector cells within an inflammatory milieu}

A reciprocal relationship in the development of $\mathrm{T}_{\text {Regs }}$ and Th17 cells has recently been described. This may underlie the propensity of $\mathrm{T}_{\text {Regs }}$ to convert to Th17 cells in the context of proinflammatory stimuli, a phenomenon that has only recently been recognized [74-76]. Under neutral conditions in vitro, transforming growth factor beta can shift the balance towards functional FoxP3 ${ }^{+} \mathrm{T}_{\text {Regs }}-$ whereas in the context of an inflammatory cytokine milieu (IL-1 $\beta$, IL-2, IL-6, IL-15, IL-21, IL-23), functional $\mathrm{T}_{\text {Regs }}$ convert towards IL-17-producing, nonfunctional $\mathrm{T}_{\text {Regs }}^{\text {Regs }}$. The relatively novel notion of T-cell lineage plasticity is of interest in relation to many papers describing nonfunctional $\mathrm{T}_{\text {Regs }}$ in several autoimmune conditions, including AAV. Our hypothesis is that these nonfunctional Fox $\mathrm{P3}^{+} \mathrm{T}$ cells have lost their suppressive function due to co-expression of a second Th17 lineage-associated transcription factor ROR $\gamma$ t that interferes with Foxp3 activity [77]. Recently, different isoforms of FoxP3 have been investigated in human $\mathrm{T}_{\text {Regs }}$ that have been shown to impact $\mathrm{T}_{\text {Reg }}$ function and lineage commitment. More specifically, the full-length isoform (FoxP3fl) - but not the isoform lacking exon 2 (FoxP3 $\triangle 2$ ) - interacts with RoRyt and inhibits the expression of genes that define Th17 cells [78-80]. Based on the aforementioned data, the putative nonfunctional $\mathrm{T}_{\text {Regs }}$ described in AAV may lack their suppressive function due to upregulation of the FoxP3A2 isoform that fails to inhibit RORyt-mediated IL-17A mRNA transcription. Upon stimulation in an inflamed context, these cells convert into IL-17producing effector $\mathrm{T}$ cells.

Evidence from several groups of investigators, including our own, support this hypothesis of conversion of $\mathrm{T}_{\text {Regs }}$ into effector IL-17-secreting cells in AAV. As mentioned before, we found a significant increase in the percentage of FoxP3 ${ }^{+} \mathrm{CD} 25^{\text {High }} \mathrm{T}_{\text {Regs }}$ with a defective regulatory function in $\mathrm{AAV}$ patients in remission as compared with healthy controls. Furthermore, we demonstrated a concurrent increase in the percentage of Th17 cells upon in vitro stimulation of peripheral blood samples from AAV patients. Consistent with this, patients with AAV had significantly higher serum levels of IL-17 compared with healthy controls [62]. Importantly, increased serum levels of IL-17 in AAV patients 


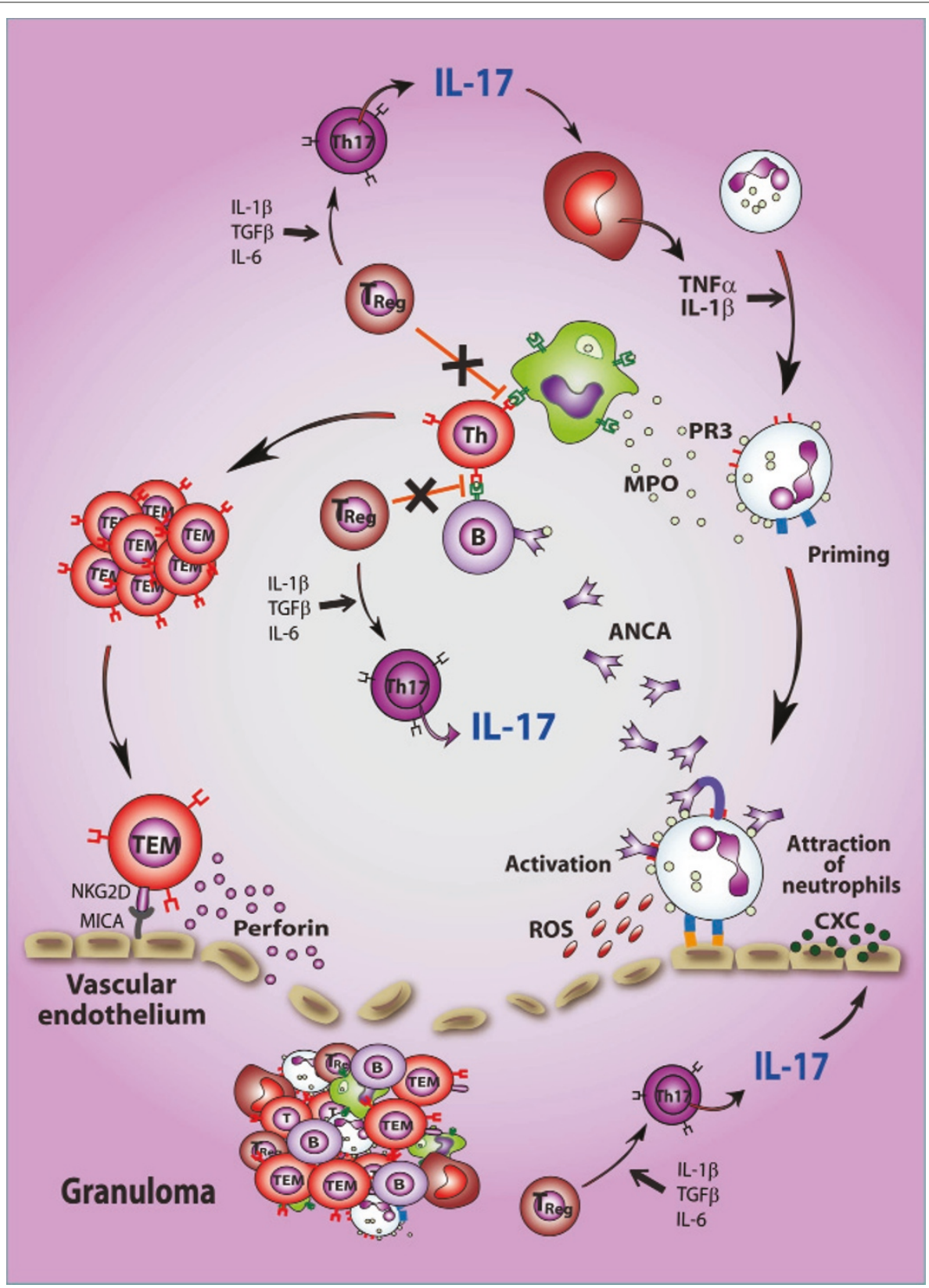

Figure 1. Proposed pathophysiological mechanisms of anti-neutrophil cytoplasmic autoantibody-associated vasculitides. Inflammatory cytokines (IL-1 $\beta$, IL-6, transforming growth factor beta (TGF $\beta)$ ) released due to bacterial or viral infections can promote skewing of a subset of functional regulatory T cells $\left(\mathrm{T}_{\text {Regs }}\right)$ towards IL-17-producing nonfunctional $\mathrm{T}_{\text {Regs }}$. These IL-17-producing cells play a key role in disease onset through their cytokine IL-17. This cytokine induces CXC chemokine release from the target tissue that will attract neutrophils to the site of inflammation. In addition, IL-17 stimulates the release of IL-1 $\beta$ and TNFa from macrophages, which causes upregulation of the expression of endothelial adhesion molecules and induces translocation of proteinase-3 (PR3) and myeloperoxidase (MPO) to the neutrophil membrane (priming). Released PR3 and MPO can be processed and presented by antigen-presenting cells (APC) to T-helper cells. Since $T_{\text {Regs }}$ are converted into nonfunctional IL-17producing cells that fail to inhibit this autoimmune response, autoreactive T cells may undergo repeated stimulation by PR3-pulsed or MPO-pulsed APC, resulting in a pool of effector memory T cells $\left(T_{E M}\right)$. In addition, PR3-stimulated T-helper cells act on B cells. The presence of IL-17 can enhance the production of anti-neutrophil cytoplasmic autoantibody (ANCA) by autoreactive B cells. Subsequently, ANCA binds to PR3 or MPO on primed neutrophils that adhere to endothelial cells, which enhances neutrophil activation resulting in degranulation and release of reactive oxygen species (ROS) and proteolytic enzymes that can damage vascular endothelial cells. Moreover, persistent activation of T-helper cells by PR3 or MPO, together with the breakdown of $\mathrm{T}_{\text {Reg }}$-mediated self-tolerance mechanisms, will induce autoreactive $C D 4^{+} T_{E M}$ expansion. Expanded $C D 4^{+} T_{E M}$ upregulate their killer immunoglobulin-like receptor (NKG2D) and interact with their ligand (major histocompatibility complex class-I chain-related molecule A (MICA)) on vascular endothelial cells, which in turn enhances their cytotoxic function and kills target cells in a perforin-dependent and granzymedependent way, ending up in vasculitis. 
correlated significantly with increased levels of the cytokines that are involved in the conversion of $\mathrm{T}_{\text {Regs }}$ into Th17 cells; that is, IL-1 $\beta$, IL-23 and IL-6 [62]. In addition, patients with active CSS showed an increased frequency of Th17 cells with a decrease in the frequency of IL-10producing $\mathrm{T}_{\text {Regs }}$, whereas an inverse result was observed in CSS patients with inactive disease [63]. The aforementioned data appear to support a link between the conversion of $\mathrm{T}_{\text {Regs }}$ into Th17 cells and disease activity in AAV (Figure 1).

\section{Therapeutic targets in patients with AAV}

Because Th17 cells contribute to inflammation and granuloma formation, this T-cell subset could be a novel therapeutic target for AAV. Depletion of Th17 cells by targeting specific surface proteins may be difficult as Th17 cells share many surface markers with other T-cell subsets. A therapeutic approach targeting its cytokine (that is, IL-17) would therefore be more feasible. Indeed, neutralizing IL-17 by anti-IL-17 antibody or by soluble IL-17 receptors reduces inflammation and bone erosion in various animal arthritis models [81]. Interestingly, humanized anti-IL-17 mAbs - including AIN457 and LY2439821, which neutralize the biologic activity of IL-17 - are in clinical trials. These biologicals have been shown to induce clinically relevant responses in patients with psoriasis, rheumatoid arthritis, and non-infectious uveitis, compared with placebo without safety issues $[82,83]$. Neutralization of IL-17 could therefore represent a novel therapeutic approach for patients with AAV.

On the other hand, $\mathrm{CD} 4^{+} \mathrm{T}_{\mathrm{EM}}$ - supposed to act as a key trigger of disease expression and relapse in AAV may also serve as a therapeutic target. Selective targeting of $\mathrm{CD}^{+} \mathrm{T}_{\mathrm{EM}}$ without impairing other parts of the humoral and cellular immune system could be a major step forward in the treatment of AAV. NKG2D blockade by anti-NKG2D antibodies has been reported to prevent autoimmune diabetes in NOD mice [84]. Blocking of NKG2D could be a new strategy in the treatment of AAV. Other studies have revealed that targeting of the voltagegated Kv1.3 channel, which is highly expressed on activated $\mathrm{CD}^{+} \mathrm{T}_{\mathrm{EM}}$, provides a specific immunomodulatory approach $[85,86]$. Blockade of the Kv1.3 channel by ShK(L5) amide effectively prevented autoimmune disease in the EAE model of multiple sclerosis and suppressed delayed-type hypersensitivity in rats $[85,86]$. The selective targeting of $\mathrm{CD}^{+} \mathrm{T}_{\mathrm{EM}}$ using ShK(L5) amide and/or blocking the NKG2D-MICA interaction by anti-NKG2D antibodies may therefore hold therapeutic promise for AAV.

\section{Conclusion}

$\mathrm{CD}^{+} \mathrm{T}_{\mathrm{EM}}$ seem to be involved in tissue damage and renal injury in patients with AAV. Besides $C D 4^{+} \mathrm{T}_{\mathrm{EM}}$, impaired
$\mathrm{T}_{\text {Reg }}$ function and an increased Th17 response are also reported in AAV patients. During the past 2 years, multiple studies indicate a link between $\mathrm{T}_{\text {Regs }}$ and Th17 cells. Indeed, in the context of an inflammatory cytokine milieu, conversion of $\mathrm{T}_{\text {Regs }}$ into IL-17-producing cells has been demonstrated. Evidence from several studies supports this conversion in AAV patients. Defective $\mathrm{T}_{\text {Reg }}$ function in AAV patients can thus be explained by their conversion into effector Th17 cells. Instead of suppressing autoreactive responses, these converted $\mathrm{T}_{\text {Regs }}$ - through production of IL-17 - can participate in granuloma formation and tissue injury, which contribute to necrotizing granulomatous vasculitis in AAV patients. The mechanisms underlying the conversion of suppressive $\mathrm{T}_{\text {Regs }}$ into nonfunctional $\mathrm{T}_{\text {Regs }}$ in AAV await further investigation. This novel view into the role of converted $\mathrm{T}_{\text {Regs }}$ in the pathophysiology of vasculitis will improve our understanding of AAV pathogenesis, which may lead to the identification of new biomarkers and targets for therapeutic intervention.

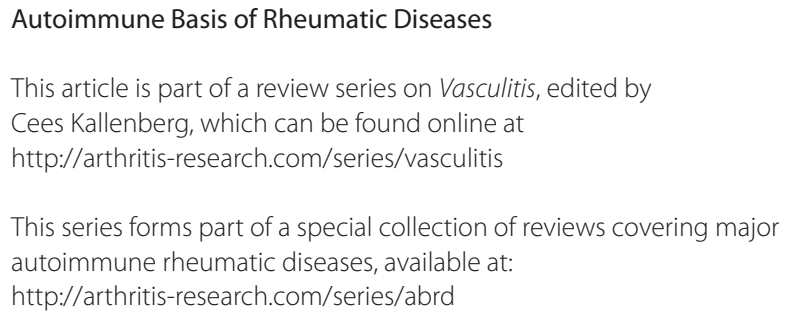

This series forms part of a special collection of reviews covering major autoimmune rheumatic diseases, available at:

http://arthritis-research.com/series/abrd

\section{Abbreviations}

AAV, anti-neutrophil cytoplasmic autoantibody-associated vasculitides; ANCA, anti-neutrophil cytoplasmic autoantibody; CSS, Churg-Strauss syndrome; EAE, experimental autoimmune encephalomyelitis; FoxP3, transcription factor forkhead box P3; IFN, interferon; IL, interleukin; mAb, monoclonal antibody; MICA, major histocompatibility complex class-I chain-related molecule A; MPA, microscopic polyangiitis; MPO, myeloperoxidase; NK, natural killer; PR3, proteinase-3; $T_{E M^{\prime}}$ effector memory $T$ cells; Th, T-helper type; TNF, tumor necrosis factor; $T_{\text {Reg' }}$, regulatory $T$ cell; $W G$, Wegener's granulomatosis.

\section{Competing interests}

The authors declare they have no competing interests.

\section{Author details}

'Department of Rheumatology and Clinical Immunology, University Medical Center Groningen, Hanzeplein 1, 9713 GZ Groningen, The Netherlands. ${ }^{2}$ Department of Rheumatology, Vasculitis Center UKSH \& Clinical Center Bad Bramstedt, University of Lübeck, Ratzeburger Allee 160, 23562 Lübeck, Germany.

\section{Published: 23 August 2011}

\section{References}

1. Jennette JC, Falk RJ: Small-vessel vasculitis. N Engl J Med 1997, 337:1512-1523.

2. Kallenberg CG, Brouwer E, Weening JJ, Tervaert JW: Anti-neutrophil cytoplasmic antibodies: current diagnostic and pathophysiological potential. Kidney Int 1994, 46:1-15.

3. Xiao H, Heeringa P, Hu P, Liu Z, Zhao M, Aratani Y, Maeda N, Falk RJ, Jennette $J C:$ Antineutrophil cytoplasmic autoantibodies specific for myeloperoxidase cause glomerulonephritis and vasculitis in mice. J Clin 
Invest 2002, 110:955-963

4. van Timmeren MM, van der Veen BS, Stegeman CA, Petersen AH, Hellmark T, Collin M, Heeringa P: IgG glycan hydrolysis attenuates ANCA-mediated glomerulonephritis. J Am Soc Nephrol 2010, 21:1103-1114.

5. Bansal PJ, Tobin MC: Neonatal microscopic polyangiitis secondary to transfer of maternal myeloperoxidase-antineutrophil cytoplasmic antibody resulting in neonatal pulmonary hemorrhage and renal involvement. Ann Allergy Asthma Immunol 2004, 93:398-401.

6. Pfister H, Ollert M, Frohlich LF, Quintanilla-Martinez L, Colby TV, Specks U, Jenne DE: Antineutrophil cytoplasmic autoantibodies against the murine homolog of proteinase 3 (Wegener autoantigen) are pathogenic in vivo. Blood 2004, 104:1411-1418.

7. Kessenbrock K, Frohlich L, Sixt M, Lammermann T, Pfister H, Bateman A, Belaaouaj A, Ring J, Ollert M, Fassler R, Jenne DE: Proteinase 3 and neutrophil elastase enhance inflammation in mice by inactivating antiinflammatory progranulin. J Clin Invest 2008, 118:2438-2447.

8. Primo VC, Marusic S, Franklin CC, Goldmann WH, Achaval CG, Smith RN, Arnaout MA, Nikolic B: Anti-PR3 immune responses induce segmental and necrotizing glomerulonephritis. Clin Exp Immunol 2010, 159:327-337.

9. Komocsi A, Lamprecht P, Csernok E, Mueller A, Holl-Ulrich K, Seitzer U, Moosig F, Schnabel A, Gross WL: Peripheral blood and granuloma CD4(+)CD28(-) T cells are a major source of interferon-gamma and tumor necrosis factoralpha in Wegener's granulomatosis. Am J Pathol 2002, 160:1717-1724.

10. Lamprecht P, Moosig F, Csernok E, Seitzer U, Schnabel A, Mueller A, Gross WL: CD28 negative $T$ cells are enriched in granulomatous lesions of the respiratory tract in Wegener's granulomatosis. Thorax 2001, 56:751-757.

11. Abdulahad WH, van der Geld YM, Stegeman CA, Kallenberg CG: Persistent expansion of $\mathrm{CD}^{+}$effector memory T cells in Wegener's granulomatosis. Kidney Int 2006, 70:938-947.

12. Berden AE, Kallenberg CG, Savage CO, Yard BA, Abdulahad WH, de Heer E, Bruijn JA, Bajema IM: Cellular immunity in Wegener's granulomatosis: characterizing T lymphocytes. Arthritis Rheum 2009, 60:1578-1587.

13. Lockwood CM, Thiru S, Isaacs JD, Hale G, Waldmann H: Long-term remission of intractable systemic vasculitis with monoclonal antibody therapy. Lancet 1993, 341:1620-1622.

14. Schmitt WH, Hagen EC, Neumann I, Nowack R, Flores-Suarez LF, van der Woude FJ: Treatment of refractory Wegener's granulomatosis with antithymocyte globulin (ATG): an open study in 15 patients. Kidney Int 2004, 65:1440-1448

15. Brouwer E, Tervaert JW, Horst G, Huitema MG, van der GM, Limburg PC, Kallenberg CG: Predominance of $\mathrm{IgG}_{\text {and }}$ an $\mathrm{Ig}_{4}$ subclasses of antineutrophil cytoplasmic autoantibodies (ANCA) in patients with Wegener's granulomatosis and clinically related disorders. Clin Exp Immunol 1991, 83:379-386

16. Falk RJ, Jennette JC: ANCA small-vessel vasculitis. J Am Soc Nephro/ 1997, 8:314-322.

17. Gephardt GN, Ahmad M, Tubbs RR: Pulmonary vasculitis (Wegener's granulomatosis). Immunohistochemical study of T and B cell markers. Am J Med 1983, 74:700-704.

18. Cunningham MA, Huang XR, Dowling JP, Tipping PG, Holdsworth SR: Prominence of cell-mediated immunity effectors in 'pauci-immune' glomerulonephritis. J Am Soc Nephrol 1999, 10:499-506

19. Weidner S, Carl M, Riess R, Rupprecht HD: Histologic analysis of renal leukocyte infiltration in antineutrophil cytoplasmic antibody-associated vasculitis: importance of monocyte and neutrophil infiltration in tissue damage. Arthritis Rheum 2004, 50:3651-3657.

20. Muller A, Trabandt A, Gloeckner-Hofmann K, Seitzer U, Csernok E, Schonermarck U, Feller AC, Gross WL: Localized Wegener's granulomatosis: predominance of CD26 and IFN- $\gamma$ expression. J Pathol 2000, 192:113-120.

21. Saunders BM, Frank AA, Orme IM, Cooper AM: CD4 is required for the development of a protective granulomatous response to pulmonary tuberculosis. Cell Immunol 2002, 216:65-72.

22. Di Perri G, Cazzadori A, Vento S, Bonora S, Malena M, Bontempini L, Lanzafame M, Allegranzi B, Concia E: Comparative histopathological study of pulmonary tuberculosis in human immunodeficiency virus-infected and non-infected patients. Tuber Lung Dis 1996, 77:244-249.

23. Horsburgh $C R$, Jr: Mycobacterium avium complex infection in the acquired immunodeficiency syndrome. N Engl J Med 1991, 324:1332-1338.

24. Ruth AJ, Kitching AR, Kwan RY, Odobasic D, Ooi JD, Timoshanko JR, Hickey MJ, Holdsworth SR: Anti-neutrophil cytoplasmic antibodies and effector CD4 ${ }^{+}$ cells play nonredundant roles in anti-myeloperoxidase crescentic glomerulonephritis. J Am Soc Nephrol 2006, 17:1940-1949.

25. Popa ER, Franssen CF, Limburg PC, Huitema MG, Kallenberg CG, Tervaert JW: In vitro cytokine production and proliferation of T cells from patients with anti-proteinase 3- and antimyeloperoxidase-associated vasculitis, in response to proteinase 3 and myeloperoxidase. Arthritis Rheum 2002, 46:1894-1904.

26. Gutfleisch J, Baumert E, Wolff-Vorbeck G, Schlesier M, Strutz HJ, Peter HH Increased expression of CD25 and adhesion molecules on peripheral blood lymphocytes of patients with Wegener's granulomatosis (WG) and ANCA positive vasculitides. Adv Exp Med Biol 1993, 336:397-404.

27. Schlesier M, Kaspar T, Gutfleisch J, Wolff-Vorbeck G, Peter HH: Activated CD4 and CD8 ${ }^{+}$T-cell subsets in Wegener's granulomatosis. Rheumatol Int 1995, 14:213-219.

28. Popa ER, Stegeman CA, Bos NA, Kallenberg CG, Tervaert JW: Differential B- and T-cell activation in Wegener's granulomatosis. J Allergy Clin Immunol 1999, 103:885-894.

29. Marinaki S, Kalsch Al, Grimminger P, Breedijk A, Birck R, Schmitt WH, Weiss C, van der Woude FJ, Yard BA: Persistent T-cell activation and clinical correlations in patients with ANCA-associated systemic vasculitis. Nephrol Dial Transplant 2006, 21:1825-1832

30. Seta N, Tajima M, Kobayashi S, Kawakami Y, Hashimoto H, Kuwana M: Autoreactive T-cell responses to myeloperoxidase in patients with antineutrophil cytoplasmic antibody-associated vasculitis and in healthy individuals. Mod Rheumatol 2008, 18:593-600.

31. Capraru D, Muller A, Csernok E, Gross WL, Holl-Ulrich K, Northfield J, Klenerman P, Herlyn K, Holle J, Gottschlich S, Voswinkel J, Spies T, Fagin U, Jabs WJ, Lamprecht P: Expansion of circulating NKG2D+ effector memory T-cells and expression of NKG2D-ligand MIC in granulomaous lesions in Wegener's granulomatosis. Clin Immunol 2008, 127:144-150

32. Lamprecht P, Vargas Cuero AL, Muller A, Csernok E, Voswinkel J, Maass M, Solbach W, Gross WL, Klenerman P: Alterations in the phenotype of CMVspecific and total $C D 8^{+} \mathrm{T}$-cell populations in Wegener's granulomatosis. Cell Immunol 2003, 224:1-7.

33. Coulomb-L'Hermine A, Capron F, Zou W, Piard F, Galateau F, Laurent P, Crevon MC, Galanaud P, Emilie D: Expression of the chemokine RANTES in pulmonary Wegener's granulomatosis. Hum Pathol 2001, 32:320-326.

34. Sakatsume M, Xie Y, Ueno M, Obayashi H, Goto S, Narita I, Homma N, Tasaki K, Suzuki Y, Gejyo F: Human glomerulonephritis accompanied by active cellular infiltrates shows effector T cells in urine. J Am Soc Nephrol 2001, 12:2636-2644

35. Kiene M, Csernok E, Muller A, Metzler C, Trabandt A, Gross WL: Elevated interleukin-4 and interleukin-13 production by T cell lines from patients with Churg-Strauss syndrome. Arthritis Rheum 2001, 44:469-473.

36. Hagen EC, de Keizer RJ, Andrassy K, van Boven WP, Bruijn JA, van Es LA, van der Woude FJ: Compassionate treatment of Wegener's granulomatosis with rabbit anti-thymocyte globulin. Clin Nephrol 1995, 43:351-359.

37. Ordonez L, Bernard I, L'faqihi-Olive FE, Tervaert JW, Damoiseaux J, Saoudi A: CD45RC isoform expression identifies functionally distinct $T$ cell subsets differentially distributed between healthy individuals and AAV patients. PLoS One 2009, 4:e5287

38. Moosig F, Csernok E, Wang G, Gross WL: Costimulatory molecules in Wegener's granulomatosis (WG): lack of expression of $\mathrm{CD} 28$ and preferential up-regulation of its ligands B7-1 (CD80) and B7-2 (CD86) on T cells. Clin Exp Immunol 1998, 114:113-118.

39. Appay V: The physiological role of cytotoxic CD4(+) T-cells: the holy grail? Clin Exp Immunol 2004, 138:10-13.

40. Abdulahad WH, Kallenberg CG, Limburg PC, Stegeman CA: Urinary CD4 effector memory $T$ cells reflect renal disease activity in antineutrophil cytoplasmic antibody-associated vasculitis. Arthritis Rheum 2009, 60:2830-2838

41. Wilde B, Dolff S, Cai X, Specker C, Becker J, Totsch M, Costabel U, Durig J, Kribben A, Tervaert JW, Schmid KW, Witzke O: CD4+CD25+ T-cell populations expressing CD134 and GITR are associated with disease activity in patients with Wegener's granulomatosis. Nephrol Dial Transplant 2009, 24:161-171.

42. Imura A, Hori T, Imada K, Ishikawa T, Tanaka Y, Maeda M, Imamura S, Uchiyama T: The human OX40/gp34 system directly mediates adhesion of activated T cells to vascular endothelial cells. J Exp Med 1996, 183:2185-2195.

43. Bauer S, Groh V, Wu J, Steinle A, Phillips JH, Lanier LL, Spies T: Activation of NK cells and T cells by NKG2D, a receptor for stress-inducible MICA. Science 1999, 285:727-729.

44. Allez M, Tieng V, Nakazawa A, Treton X, Pacault V, Dulphy N, Caillat-Zucman S, 
Paul P, Gornet JM, Douay C, Ravet S, Tamouza R, Charron D, Lemann M, Mayer $\mathrm{L}$, Toubert A: $\mathrm{CD} 4^{+} \mathrm{NKG} 2 \mathrm{D}^{+} \mathrm{T}$ cells in Crohn's disease mediate inflammatory and cytotoxic responses through MICA interactions. Gastroenterology 2007, 132:2346-2358.

45. Holmen C, Elsheikh E, Stenvinkel P, Qureshi AR, Pettersson E, Jalkanen S, Sumitran-Holgersson S: Circulating inflammatory endothelial cells contribute to endothelial progenitor cell dysfunction in patients with vasculitis and kidney involvement. J Am Soc Nephrol 2005, 16:3110-3120.

46. Abdulahad WH, Stegeman CA, Kallenberg CG: Review article: the role of CD4(+) T cells in ANCA-associated systemic vasculitis. Nephrology (Carlton) 2009, 14:26-32.

47. Schonermarck U, Csernok E, Trabandt A, Hansen H, Gross WL: Circulating cytokines and soluble CD23, CD26 and CD30 in ANCA-associated vasculitides. Clin Exp Rheumatol 2000, 18:457-463.

48. Wang G, Hansen H, Tatsis E, Csernok E, Lemke H, Gross WL: High plasma levels of the soluble form of $\mathrm{CD} 30$ activation molecule reflect disease activity in patients with Wegener's granulomatosis. Am J Med 1997, 102:517-523.

49. Lamprecht P, Bruhl H, Erdmann A, Holl-Ulrich K, Csernok E, Seitzer U, Mack M Feller AC, Reinhold-Keller E, Gross WL, Muller A: Differences in CCR5 expression on peripheral blood CD4 ${ }^{+} \mathrm{CD} 28^{-} \mathrm{T}$-cells and in granulomatous lesions between localized and generalized Wegener's granulomatosis. Clin Immunol 2003, 108:1-7.

50. Cua DJ, Sherlock J, Chen Y, Murphy CA, Joyce B, Seymour B, Lucian L, To W, Kwan S, Churakova T, Zurawski S, Wiekowski M, Lira SA, Gorman D, Kastelein RA, Sedgwick JD: Interleukin-23 rather than interleukin-12 is the critical cytokine for autoimmune inflammation of the brain. Nature 2003, 421:744-748.

51. Murphy CA, Langrish CL, Chen Y, Blumenschein W, McClanahan T, Kastelein RA, Sedgwick JD, Cua DJ: Divergent pro- and antiinflammatory roles for IL-23 and IL-12 in joint autoimmune inflammation. J Exp Med 2003, 198:1951-1957.

52. Komiyama Y, Nakae S, Matsuki T, Nambu A, Ishigame H, Kakuta S, Sudo K, Iwakura Y: IL-17 plays an important role in the development of experimental autoimmune encephalomyelitis. J Immunol 2006, 177:566-573.

53. Willenborg DO, Fordham S, Bernard CC, Cowden WB, Ramshaw IA: IFNplays a critical down-regulatory role in the induction and effector phase of myelin oligodendrocyte glycoprotein-induced autoimmune encephalomyelitis. J Immunol 1996, 157:3223-3227.

54. Murphy AC, Lalor SJ, Lynch MA, Mills KH: Infiltration of Th1 and Th17 cells and activation of microglia in the CNS during the course of experimental autoimmune encephalomyelitis. Brain Behav Immun 2010, 24:641-651.

55. Ye P, Rodriguez FH, Kanaly S, Stocking KL, Schurr J, Schwarzenberger P, Oliver P, Huang W, Zhang P, Zhang J, Shellito JE, Bagby GJ, Nelson S, Charrier K, Peschon JJ, Kolls JK: Requirement of interleukin 17 receptor signaling for lung CXC chemokine and granulocyte colony-stimulating factor expression, neutrophil recruitment, and host defense. J Exp Med 2001, 194:519-527.

56. Ma CS, Chew GY, Simpson N, Priyadarshi A, Wong M, Grimbacher B, Fulcher DA, Tangye SG, Cook MC: Deficiency of Th17 cells in hyper IgE syndrome due to mutations in STAT3. J Exp Med 2008, 205:1551-1557.

57. Ivanov S, Bozinovski S, Bossios A, Valadi H, Vlahos R, Malmhall C, Sjostrand M, Kolls JK, Anderson GP, Linden A: Functional relevance of the IL-23-IL-17 axis in lungs in vivo. Am J Respir Cell Mol Biol 2007, 36:442-451.

58. Niebuhr M, Gathmann M, Scharonow H, Mamerow D, Mommert S, Balaji H, Werfel T: Staphylococcal a-toxin is a strong inducer of interleukin (IL)-17 in humans. Infect Immun 2011, 79:1615-1622.

59. Stegeman CA, Tervaert JW, Sluiter WJ, Manson WL, de Jong PE, Kallenberg CG: Association of chronic nasal carriage of Staphylococcus aureus and higher relapse rates in Wegener granulomatosis. Ann Intern Med 1994, 120:12-17.

60. Laudien M, Gadola SD, Podschun R, Hedderich J, Paulsen J, Reinhold-Keller E, Csernok E, Ambrosch P, Hellmich B, Moosig F, Gross WL, Sahly H, Lamprecht P: Nasal carriage of Staphylococcus aureus and endonasal activity in Wegener's granulomatosis as compared to rheumatoid arthritis and chronic rhinosinusitis with nasal polyps. Clin Exp Rheumatol 2010, 28:51-55.

61. Abdulahad WH, Stegeman CA, Limburg PC, Kallenberg CG: Skewed distribution of Th17 lymphocytes in patients with Wegener's granulomatosis in remission. Arthritis Rheum 2008, 58:2196-2205.

62. Nogueira E, Hamour S, Sawant D, Henderson S, Mansfield N, Chavele KM, Pusey CD, Salama AD: Serum IL-17 and IL-23 levels and autoantigen-specific Th17 cells are elevated in patients with ANCAassociated vasculitis. Nephrol Dial Transplant 2010, 25:2209-2217.

63. Saito H, Tsurikisawa N, Tsuburai T, Oshikata C, Akiyama K: Cytokine production profile of $\mathrm{CD}^{+} T$ cells from patients with active Churg-Strauss syndrome tends toward Th17. Int Arch Allergy Immunol 2009, 149(Suppl 1):61-65.

64. Laan M, Cui ZH, Hoshino H, Lotvall J, Sjostrand M, Gruenert DC, Skoogh BE, Linden A: Neutrophil recruitment by human IL-17 via C-X-C chemokine release in the airways. J/mmunol 1999, 162:2347-2352.

65. Panettieri RA, Jr, Lazaar AL, Pure E, Albelda SM: Activation of cAMPdependent pathways in human airway smooth muscle cells inhibits TNFa-induced ICAM-1 and VCAM-1 expression and T lymphocyte adhesion. J Immuno/ 1995, 154:2358-2365.

66. Jovanovic DV, Di Battista JA, Martel-Pelletier J, Jolicoeur FC, He Y, Zhang M, Mineau F, Pelletier JP: IL-17 stimulates the production and expression of proinflammatory cytokines, IL- $\beta$ and TNF-a, by human macrophages. J Immunol 1998, 160:3513-3521.

67. Hsu HC, Yang P, Wang J, Wu Q, Myers R, Chen J, Yi J, Guentert T, Tousson A, Stanus AL, Le TV, Lorenz RG, Xu H, Kolls JK, Carter RH, Chaplin DD, Williams RW, Mountz JD: Interleukin 17-producing Thelper cells and interleukin 17 orchestrate autoreactive germinal center development in autoimmune BXD2 mice. Nat Immunol 2008, 9:166-175.

68. Valencia $\mathrm{X}$, Lipsky PE: $\mathrm{CD}^{+} \mathrm{CD}_{25} 5^{+} \mathrm{FoxP}^{+}$regulatory $\mathrm{T}$ cells in autoimmune diseases. Nat Clin Pract Rheumatol 2007, 3:619-626.

69. Abdulahad WH, Stegeman CA, van der Geld YM, Doornbos van der MB, Limburg PC, Kallenberg CG: Functional defect of circulating regulatory $\mathrm{CD} 4^{+} \mathrm{T}$ cells in patients with Wegener's granulomatosis in remission. Arthritis Rheum 2007, 56:2080-2091.

70. Klapa S, Mueller A, Csernok E, Fagin U, Klenerman P, Holl-Ulrich K, Gross WL, Lamprecht P: Lower numbers of FoxP3 and CCR4 co-expressing cells in an elevated subpopulation of $\mathrm{CD} 4^{+} \mathrm{CD} 25^{\text {high }}$ regulatory T cells from Wegener's granulomatosis. Clin Exp Rheumatol 2010, 28:72-80.

71. Morgan MD, Day CJ, Piper KP, Khan N, Harper L, Moss PA, Savage CO: Patients with Wegener's granulomatosis demonstrate a relative deficiency and functional impairment of T-regulatory cells. Immunology 2010, 130:64-73.

72. Chavele KM, Shukla D, Keteepe-Arachi T, Seidel JA, Fuchs D, Pusey CD, Salama AD: Regulation of myeloperoxidase-specific $T$ cell responses during disease remission in antineutrophil cytoplasmic antibody-associated vasculitis: the role of $\mathrm{T}_{\text {reg }}$ cells and tryptophan degradation. Arthritis Rheum 2010, 62:1539-1548.

73. Tsurikisawa N, Saito H, Tsuburai T, Oshikata C, Ono E, Mitomi H, Akiyama K. Differences in regulatory T cells between Churg-Strauss syndrome and chronic eosinophilic pneumonia with asthma. J Allergy Clin Immunol 2008, 122:610-616.

74. Koenen HJ, Smeets RL, Vink PM, van Rijssen E, Boots AM, Joosten I: Human CD25 ${ }^{\text {high }}$ Foxp $3^{\text {pos }}$ regulatory T cells differentiate into IL-17-producing cells. Blood 2008, 112:2340-2352.

75. Ayyoub M, Deknuydt F, Raimbaud I, Dousset C, Leveque L, Bioley G, Valmori D: Human memory FOXP3 ${ }^{+}$Tregs secrete IL-17 ex vivo and constitutively express the $\mathrm{T}(\mathrm{H}) 17$ lineage-specific transcription factor RORyt. Proc Natl Acad Sci U S A 2009, 106:8635-8640.

76. Voo KS, Wang YH, Santori FR, Boggiano C, Wang YH, Arima K, Bover L, Hanabuchi S, Khalili J, Marinova E, Zheng B, Littman DR, Liu YJ: Identification of IL-17-producing FOXP3 ${ }^{+}$regulatory T cells in humans. Proc Natl Acad Sci USA 2009, 106:4793-4798.

77. Abdulahad WH, Boots AM, Kallenberg CG: FoxP3 $3^{+} \mathrm{CD} 4^{+} \mathrm{T}$ cells in systemic autoimmune diseases: the delicate balance between true regulatory T cells and effector Th-17 cells. Rheumatology (Oxford) 2010, 50:646-656

78. Du J, Huang C, Zhou B, Ziegler SF: Isoform-specific inhibition of RORamediated transcriptional activation by human FOXP3. J Immuno/ 2008, 180:4785-4792.

79. Ichiyama K, Yoshida H, Wakabayashi Y, Chinen T, Saeki K, Nakaya M, Takaesu G, Hori S, Yoshimura A, Kobayashi T: Foxp3 inhibits RORyt-mediated IL-17A mRNA transcription through direct interaction with RORyt. J Biol Chem 2008, 283:17003-17008

80. Zhou L, Lopes JE, Chong MM, Ivanov II, Min R, Victora GD, Shen Y, Du J, Rubtsov YP, Rudensky AY, Ziegler SF, Littman DR: TGF- $\beta$-induced Foxp3 inhibits $\mathrm{T}(\mathrm{H}) 17$ cell differentiation by antagonizing RORyt function. Nature 2008, 453:236-240

81. Lubberts E: IL-17/Th17 targeting: on the road to prevent chronic destructive arthritis? Cytokine 2008, 41:84-91. 
82. Genovese MC, Van den Bosch F, Roberson SA, Bojin S, Biagini IM, Ryan P, Sloan-Lancaster J: LY2439821, a humanized anti-interleukin-17 monoclonal antibody, in the treatment of patients with rheumatoid arthritis: a phase I randomized, double-blind, placebo-controlled, proof-of-concept study. Arthritis Rheum 2010, 62:929-939.

83. Hueber W, Patel DD, Dryja T, Wright AM, Koroleva I, Bruin G, Antoni C, Draelos Z, Gold MH, Durez P, Tak PP, Gomez-Reino JJ, Foster CS, Kim RY, Samson CM, Falk NS, Chu DS, Callanan D, Nguyen QD, Rose K, Haider A, Di Padova F: Effects of AIN457, a fully human antibody to interleukin-17A, on psoriasis, rheumatoid arthritis, and uveitis. Sci Trans/Med 2010, 2:52ra72.

84. Ogasawara K, Hamerman JA, Ehrlich LR, Bour-Jordan H, Santamaria P, Bluestone JA, Lanier LL: NKG2D blockade prevents autoimmune diabetes in NOD mice. Immunity 2004, 20:757-767.
85. Beeton C, Wulff H, Barbaria J, Clot-Faybesse O, Pennington M, Bernard D, Cahalan MD, Chandy KG, Beraud E: Selective blockade of T lymphocyte K(+) channels ameliorates experimental autoimmune encephalomyelitis, a model for multiple sclerosis. Proc Natl Acad Sci U S A 2001, 98:13942-13947.

86. Beeton C, Barbaria J, Giraud P, Devaux J, Benoliel AM, Gola M, Sabatier JM, Bernard D, Crest M, Beraud E: Selective blocking of voltage-gated $\mathrm{K}^{+}$ channels improves experimental autoimmune encephalomyelitis and inhibits T cell activation. J Immunol 2001, 166:936-944.

doi:10.1186/ar3362

Cite this article as: Abdulahad WH, et al:: T-helper cells as new players in ANCA-associated vasculitides. Arthritis Research \& Therapy 2011, 13:236. 